\title{
Is South Africa ready to compete in the knowledge economy?
}

\author{
A.N.M. Paterson \\ (Human Sciences Research Council, South Africa) \\ Post Graduate Diploma in Information Management \\ RAU University \\ anmpaterson@hsrc.ac.za
}

\section{Contents}

1. Introduction

2. Capacity of developing regions and economies to compete in the knowledge economy

3. African countries' response to the challenge of the knowledge economy

4. National information infrastructure

5. South Africa's position

6. Governmental role in developing countries in facilitating national competitiveness in the knowledge economy

7. Establishing long-term viability in the knowledge economy workforce through education

8. Conclusion

9. References

\section{Introduction}

The knowledge economy is founded on the production, distribution and application of knowledge to human production and economic activities (Vaile 2000:1). In a knowledge society, products and services are enriched by adding and embedding information, knowledge and ingenuity (Forsyth 1998:1, 2).

Although information and communication technologies (ICT) serve as the technical backbone to the knowledge economy, Henderson (2000:4) argues that innovation and adaptation must also be developed to ensure the survival of a company in the knowledge economy. This also applies to all national economies.

In this article it is argued that South Africa's capability to compete in the knowledge economy depends on a range of factors other than the infrastructural backbone. 
The United Nations Development Programme (UNDP) recently published a human development report that focussed on '[m]aking new technologies work for human development' (UNDP 2001). In this report, the importance of technology is recognized through the creation of a new 'Technology Achievement Index' that ranks countries according to specific measures. Although the index adopts a set of dimensions that assume a broad definition of technological innovation and supportive infrastructures, it is dominated by information technology-related measures. In this index of the report (UNDP 2001: 4549), the following African countries are given a world ranking (number in brackets): South Africa (39), Tunisia (51), Egypt (57), Algeria (58), Zimbabwe (59), Senegal (66), Ghana (67), Kenya (68), Tanzania (70), Sudan (71) and Mozambique (72). (UNDP 2001:45-49) What is quite apparent from this ranking is the marginal status of most African countries.

There are serious concerns about the current and future capacity of developing countries to harness ICT to generate and sustain their participation in global markets. Manuel Castells warns of an imminent and catastrophic fragmentation inequality, poverty and social exclusion for the southern region in the new global economy (Castells 2000). The problem of social exclusion, which is caused by inadequate or a lack of ICT, exists between and within national contexts (Hendry 2000). This is particularly true of South Africa, where the internal distribution of ICT access is extremely uneven.

Even in such circumstances, it is possible for South African niche industries to compete successfully in the knowledge economy. However, this very success is tempered by the continued existence of a large proportion of the population - the information poor - who still find themselves on the wrong side of the so-called digital divide. Two fundamental questions must be asked regarding a global knowledge economy. Firstly, can we assume that a global knowledge economy will eventually affect and benefit every household, even without government intervention and, secondly, if governments do intervene, what should they do and what sort of success can they expect?

Economists have questioned whether information technologies contribute measurably to economic growth - in rich or poor countries. They do, however, think that it is difficult, if not impossible, to separate the effects of technology from the political, social and economic context within which it is embedded. These concerns are merely noted here and will not be used to present an argument against competition in the global knowledge economy. It is assumed that whether prepared or not, no national economy can afford to 'delink' from global information connectivity and the knowledge economy. The only control that countries like South Africa have over their economic destinies is how they will compete.

\section{African countries' response to the challenge of the knowledge economy}

The Internet is the main medium for the knowledge economy. One of the most important claims made for the Internet is that it enables economic interaction irrespective of geographic location. According to this dictum, countries in underdeveloped regions like Africa should be able to connect and compete in the knowledge economy irrespective of their location. This is only partly accurate because it fails to give adequate recognition to a range of conditions that prevents access to the Internet and global economy, for example poverty, low economic growth, lack of foreign investments and resource scarcity. On this score, South Africa is in some ways vastly better off than the majority of other African countries, but at the same time cannot entirely escape such difficulties - as is clear from the decline of the domestic currency. 
massive continent-wide effort to apply ICTs to greatly accelerate Africa's economic and social development' (Adam 1998:4). This effort will be continued via Africa's five subregions. Key moments in this drive were the African Information Society Initiative (AISI), which was conceived and politically endorsed by Africans to produce a visionary statement on how Africa can make use of ICT for development.

In 1999, the first African Development Forum's key theme was 'Globalization and the Information Economy: Challenges and opportunities for Africa'. In a comprehensive document prepared for this forum, Cogburn and Adeya (1999:9) identify the importance of 'international harmonization of policy and regulatory frameworks' on policy issues relevant to the development of the information economy and electronic commerce in Africa.

The United Nations Millennium Declaration, which was adopted in September 2000, pledged the support of member nations across the globe to support Africa's efforts in combating its underdevelopment and marginalization. African leaders resolved to take joint responsibility for devising a strategy to achieve sustainable development in the 21st century. This developed into the Millennium African Recovery Programme (MAP), which was presented at the Organization of African Unity (OAU) Heads of State summit in July 2001. ICT was given priority in the programme and the document observed that 'Africa ha[d] been unable to capitalize on ICT as a tool in enhancing livelihoods and creating new business opportunities, and cross border linkages within the continent and with global markets' (South African Department of Foreign Affairs 2001:12).

The research conducted by the author examined the meaning of a national information infrastructure (NII). US, Canadian and Australian sources were consulted in an attempt to build a generic model of what an NII could or should be. It was assumed that an existing and well-developed NII would indicate whether a country was ready to compete in the knowledge economy.

This framework was used to assess the readiness of the South African economy to compete in the knowledge economy.

\section{National information infrastructure}

In 1993, the announcement of the US National Information Infrastructure (NII) initiative prompted a number of countries to produce NIIs. Superficially, the notion of an NII refers to the physical facilities or equipment that are used to store, process, transmit and display data. However, the current meaning of an NII goes much deeper than this.

National information infrastructures have existed for a long time and have continuously evolved with technological innovations (e.g. from semaphore and postal networks to digital forms of transmission). The major difference today, as stated by US NII (1997), is that 'we are imagining a future when all the independent infrastructures are combined. An advanced information infrastructure will integrate and interconnect the physical components in a technologically neutral manner so that no one industry will be favored over any other. Most importantly, the NII requires building foundations for living in the Information Age and making these technological advances useful to the public, business, libraries and other nongovernmental entities.'

The US view of the NII (National Information Infrastructure 1997) emphasizes that any NII depends not only on the physical infrastructure (or bitways), but also on the quality of the other elements including the: 
- information generated for and inside the NII;

- utility of applications and software;

- appropriateness and consistency of network standards, transmission codes and all other conventions;

- services to the NII (e.g. bandwidth services and consulting services); and

- human resources contributing to the NII (people who create information, develop applications and services, construct facilities, etc.).

In addition to the above fundamental elements, the following are also important:

- Legal frameworks (intellectual property rights, protection of transactions, security, etc.)

- Legislation and regulation of telecommunications (Bridges.org 2001:2)

- Education systems that emphasize constructivism (creative, collaborative and reflexive learning)

- Education systems that ensure the accessibility of IT skills to all learners

- A labour market that rewards life-long learning

- Effective national science, technology, research and development systems

- Appropriate government entities, for example entities like the Australian National Office of the Information Economy

- A knowledge economy trade or export industry that is coordinated, for example the Department of Trade and Industry

- Communications networks, for example roads to put ground communications infrastructures in place (ITWeb 2001:1)

- Extended universal service at affordable prices for the entire population

- International coordination, for example the Global Information Infrastructure or GII (GIIC 2002)

- Coordinated government departments to improve service to the citizens

- Improved access to government information.

It is clear that governments have a major - though not the sole - responsibility for the implementation of a sound NII to compete in the knowledge economy. Notwithstanding the primary importance of government, the full range of players from government and civil society, including private and social institutions, must be committed for a successful, sustainable and quality NII (Forsyth 1998:2).

\section{South Africa's position}

Given that the NII has a broad definition, this will not be useful to measure the readiness of South Africa to compete in the knowledge economy. Therefore, in this research a number of different measures were used to create as balanced a picture as possible. These included the:

- contribution of economic sectors associated with information or knowledge activities;

- telecommunications infrastructure and access; and

- Internet infrastructure.

\subsection{Sectoral contributions to South Africa's gross domestic profit (GDP)}

The knowledge economy is not going to wait for any country or individual to prepare itself for competition. The research conducted analysed current and future levels of competitiveness, while bearing in mind the challenging innovation that takes place elsewhere. 
There are a number of ways to measure the contribution of knowledge-based industries and services to GDP (Vaile 2000:1). Knowledge-based industries include ICT, biotechnology, education and financial and other business services. This is can be reflected in the production and delivery of the following:

- Information technology services: connectivity and systems development expertise

- Computer hardware and durables

- Consumables

- Software.

Alternatively, measures on the demand side, such as IT spending as a share of GDP, can be used.

Finally, there are estimates of the size of internal business to business (B2B) and business to consumer (B2C) markets. The B2C market in South Africa is valued at R3,9 billion and the B2B market at approximately R20 billion (University of Pretoria 2001:1). Another positive sign of the strength of the South African ICT sector is the success of companies in international markets, as exemplified by the listing of DimensionData, AquaOn-line and iTouch on overseas stock exchanges.

For the purposes of this article, key sectoral contributions are cited. It is clear that, unlike most African domestic economies, South Africa is no longer a resource-based economy, as the relative share of GDP by the services sector is much more significant. Overall, the tertiary economic sector accounts for $63,2 \%$ of the GDP. Of this specific sector, the technology intensive financial intermediation subsector has a 19,3\% share. Manufacturing accounts for only 26\% (Trade and Industrial Strategy Policies 2001). Clearly, the broad base of the South African economy has moved into more information intensive activities. The question is how competitive these activities are against international competition.

\subsection{Telecommunications infrastructure and access in South Africa}

Access to telephone lines and services is a fundamental requirement for competition in the knowledge economy. In the late 1990s, South Africa had a teledensity of 9.6 telephones for every 100 persons. This is a considerably better ratio than in other Southern African Development Countries (SADC). However, there are huge disparities between rich urban and poor rural dwellers' access. Teledensities range from 50 per 100 people in urban areas to 0,1 per 100 people in deep rural areas respectively. This implies that the opportunity to access the Internet, let alone participate in the knowledge economy, is unevenly distributed. It also implies that a large proportion of the South African population is excluded from the e-commerce market because it is too poor and/or lacks the necessary telecommunications access.

The Public Internet Terminal (PiT) project of the Department of Communications as well as the work of the Universal Service Agency is unlikely to overturn these conditions in a short period of time. The question is whether South Africa will be able to use new fibre-optic, wireless and satellite technologies to leapfrog the older landline technologies.

The use of satellite technologies in Africa makes a viable option where ground infrastructure is limited. The volume of Internet business in Africa is increasing and reports by IntelSat indicate that data traffic is expected to overtake voice traffic by 2005 (ITWeb 2001:1). Therefore, South Africa does have an opportunity to stay in the global race.

\subsection{Internet usage, bandwidth, domains and Web sites}


Table 1 (James 2001) contains statistics that illustrate Internet usage and bandwidth in southern Africa and South Africa. It is necessary to qualify the statistics by putting them in world perspective. This can be achieved by noting that Africa contains only 2,6\% of the world population of Internet users. In terms of worldwide e-commerce spending, South America, the Middle East and Africa together share 3,8\% in global spending (United States Internet Council 2000:1,2).

There are a number of metrics that can be used to estimate the levels of 'e-readiness', ecommerce and communications readiness of a country. It must be stated that these measures are not necessarily definitive, but the focus of this article does not extend to discussion of measurement, validity and reliability issues.

Based on the data regarding southern Africa, South Africa is a major player with by far the largest numbers of dial-up Internet subscribers. This gives a measure of the number of individuals who use the Internet for business purposes or as consumers. In addition, there are approximately one million corporate subscribers, including a large proportion of academic users (Media Africa 2000:1). The relatively high number of Internet service providers (ISPs) suggests that there is healthy competition in the market for Internet service provision - leaving aside for the moment the monopoly position of Telkom as a first tier provider. In addition, South Africa's available bandwidth and high number of hubs also make it the best equipped country in southern Africa to compete internationally.

The prospects for South African telecommunications development are not necessarily assured. Despite the technological advances made in South Africa, optimism about growth in the information and communication technology sectors has been dampened by the monopoly over private telecommunications networks granted by government to Telkom. The business community in South Africa has voiced serious concerns regarding expensive Internet access, low bandwidth and restrictions on the use of available infrastructure. For example, there is a ban on Voice over Internet Protocol (VOIP) to protect Telkom's revenues (Worthington-Smith 2001:262). Put bluntly, this market restriction and high cost scenario disallow competition and place cost limits on the extent to which South African entrepreneurs can enter the knowledge economy. Even though government's reason for privileging Telkom is to enable that company to roll-out infrastructure to disadvantaged areas for equity reasons, this may have a long-term negative impact on growth in ecommerce activities.

Table 1 Internet usage and international bandwidth (2001)

\begin{tabular}{|l|l|l|l|l|}
\hline Country & $\begin{array}{l}\text { Dial-up } \\
\text { Internet } \\
\text { subscribers }\end{array}$ & $\begin{array}{l}\text { Number of } \\
\text { ISPs }\end{array}$ & $\begin{array}{l}\text { International } \\
\text { bandwidth } \\
\text { KBPS } \\
\text { (kilobytes per } \\
\text { second) }\end{array}$ & $\begin{array}{l}\text { International } \\
\text { hub number }\end{array}$ \\
\hline South Africa & 750000 & 72 & 750050 & 5 \\
\hline $\begin{array}{l}\text { Southern } \\
\text { Africa* }\end{array}$ & 142850 & 57 & 43634 & 27 \\
\hline Total & 892850 & 132 & 793634 & 32 \\
\hline
\end{tabular}

* Mauritius, Botswana, Zimbabwe, Tanzania, Namibia, Mozambique, Democratic Republic of Congo, Angola, Malawi, Seychelles, Swaziland

The extent to which a national economy can integrate e-commerce can be measured by the 
number of Web sites listed under that country's domain name. Obviously, such figures are underestimates because a significant number of enterprises use the international domains (.org, .com, .net and more recently new domains such as .biz).

The size of South Africa's Internet presence is the biggest in Africa and is estimated at roughly $60 \%$ of all African users of the Internet. Table 2 (James 2001) illustrates that the main concentrations of Web sites are in business and tourism. But even these figures can be misleading, since the statistics do not differentiate between sites that are merely informative and sites that enable e-commerce transactions (James 2001).

About 5\% of the total southern population has Internet access (University of Pretoria 2001:1). This was estimated at between 1,2 to 2 million Internet users between 1999 and 2000. The reason for such divergence lies in the varying methodologies used to calculate the statistics. This is still a small number relative to the population size. There are also indications that growth in this population is beginning to slow down. Another statistic to put the size of public Internet use into perspective is that only an estimated $46 \%$ of South Africans with Internet access are active Internet users. This is a rather low activity rate compared to statistics in the UK and US (Worthington-Smith 2001:4,5).

Table 2 Domain and Web sites

\begin{tabular}{|l|l|l|l|l|l|l|}
\hline Country & Domains & \multicolumn{4}{l|}{ Web sites } & \multicolumn{4}{l|}{} \\
\hline & & Business & Media & Tourism & Other & Total \\
\hline $\begin{array}{l}\text { South } \\
\text { Africa }\end{array}$ & 187649 & 117 & 41 & 352 & 2492 & 3002 \\
\hline
\end{tabular}

When the future of South African e-commerce is examined, several aspects must be taken into account. Firstly, being favourably geographically located, South African companies could take advantage of a growing demand from African countries for the supply of ICT hardware, connectivity and information and knowledge-related services. However, this depends on an African economic recovery as well as investment in Africa's telecommunications infrastructure. If this does not occur, it means that South Africa's ecommerce entrepreneurs will have to compete in the domestic market or solely via the Internet with markets outside of Africa.

Secondly, if one examines the strength of South Africa's internal e-commerce capability, it is clear that South Africa was one of the first countries to enter this form of activity. This is reflected by evidence that the South African .za domain name was 13th on the list of the top country level domains in 2000. The question is whether this position will be retained in the future or whether low domestic economic growth and inadequate government regulatory frameworks will cause a slowdown in e-commerce infrastructure development.

\section{Governmental role in developing countries in facilitating national competitiveness in the knowledge economy}

Governments in developing countries cannot escape from their responsibilities. Cogburn and Adeya (1999:16) observe that 'most infrastructure expenditures in developing countries are publically financed' and this situation is unlikely to change (Castells 1994:55). Governments of developing countries face a further challenge where there is limited private commercial activity in the area of ICT. In terms of acquiring ICT goods and services, government 
departments usually rely on business and industry involvement (Selwyn 1999:4). This fact is recognized by the foundational National Information Infrastructure policy document of the United States (IITF 1994):

'Private industry will be responsible for virtually every major facet of the NII and the information marketplace it creates. Private industry will build and manage the networks, provide the information tools and much of the information that travels the networks, and develop many of the applications that use the networks.'

Governments of developing countries must look further afield for the supply of ICT requirements in this growing market, although cost considerations will also have to be taken into account.

Government policy on creating the internal environment for national access to the knowledge economy is not only confined to facilitating economic growth in this sector. Government also has the responsibility to engage with the challenge of developing and implementing an e-government vision. This can be measured in terms of: service maturity, delivery maturity and overall maturity, as analysed by Accenture in its second annual egovernment study of 2000. According to the results, South Africa has dropped to number 20 on a list of 22 countries (Business 2.0 2001:76).

\section{Establishing long-term viability in the knowledge economy workforce through education}

Information economy competencies in the African workforce have not been comprehensively explored. The paucity of skills has not been properly exposed, partly because the penetration of ICT into African economies has so far been very localized. Some of the first urgent calls for developing information technology competencies were from African universities and research and library systems (Madon 2000:86-88). Especially the need for appropriately skilled library and information specialists were articulated strongly (Chisenga 2000). What emerged from this work was not merely the need for high-level skills, but also the need for a schooling system that provides earlier opportunities for learners to interact with ICT. It is also clear that broadening the base of access to ICT at school level will break the current pattern where only the privileged elite benefit from technology (Madon 2000:90-101). Furthermore, such programmes, which have the potential to counter social inequality, may similarly present the opportunity to bring about greater gender equality from the formative environment of the school.

Castells $(2000: 4,5)$ emphasizes the importance of human resources for sustaining competitiveness in the global economy, arguing that 'human resources are critical ... for the essential infrastructure without which technology means nothing' and, as education and technological literacy become more important development resources that are unevenly distributed, 'countries lacking these resources become locked in their backward conditions'. Cogburn and Adeya (1999:13) support this observation by argueing that inadequate human resource development is 'crippling the ability of Africans to exploit the new generation of ICTs'. Similarly, Madon (2000:99-101) observes that the 'toughest challenge' in integrating the networked economy into developing countries is 'training users'. Also, this must take place on a large scale to feel the economic benefits.

These observations apply especially to South Africa, where the preparation of its citizens for participation in the knowledge economy remains a major challenge, especially bearing in mind the disadvantages and inequities in access to education in the recent past. We must 
also observe that in a global knowledge economy, the international mobility of skilled labour is of major concern to all nations, but especially in countries where this labour is in particularly short supply.

Lastly, the key challenge that faces developing countries especially regarding ICT is the balance that must be achieved between quickly acquiring globally available knowledge and creating indigenous knowledge (Madon 2000:99-101). This challenge is made even more complex given that the majority of the population of Africa does not and will not speak English in the foreseeable future. A major challenge is therefore to create more digital resources in indigenous languages or to ensure that appropriate access to English as the major language of the Internet is available through the education systems and for working adults.

The aims of government policies must therefore include: a) increasing educational opportunities and improving educational standards; b) changing the mindset of learners towards technologically based global entrepreneurial competition; and c) to upgrade the core ICT skills base of future cohorts of learners to improve employability (Selwyn and Brown 2000:663-675).

\section{Conclusion}

Research found that South Africa has a number of advantages over other developing countries in having more established domestic information and knowledge industries. However, the challenge will be to sustain these developments, bearing in mind the critically important contribution of human resource characteristics, including education, ingenuity and innovation - factors that make for success in the knowledge economy.

South African leaders must bear in mind that because of the flexibility and unpredictability of the knowledge economy, there is no right way to achieving an enterprise-wide or even national competitive advantage. Castells points out that there 'is not a single necessary path that all countries must follow to the informational society' (Castells 1994:55). Policy analysts Selwyn and Brown (2000) suggest that 'policy divergence does not reflect an evolutionary model of technological progression ... but rather reflects fundamental differences in political economy. It is therefore imperative that these variations ... are recognised and explored' (2000:679). This implies the possibility for countries such as South Africa to 'leap-frog the digital divide' (Grulke 1995:2).

\section{References}

Adam, R. 1998. Africa in the global information society. Address at the European Community Information Society Technology Conference, Vienna, 30 November-2 December.

Bridges.Org 2001. Spanning the digital divide: understanding and tackling issues. Annex 8 Case study: South African telecommunications policy.[Online]. Available WWW: http://www.bridges.org/spanning/annex8.html.

Business 2.0. 2001. E-government - GAP Management.

Castells, M.1994. Critical education in the new information age. Maryland: Rowman and 
Littlefield.

Castells, M. 2000. Information technology and global development. Address at the

Economic and Social Council of the United Nations, New York, 12 May 2000.

Chisenga, J. 2000. Global information and libraries in sub-Saharan Africa. Library Management 21(4):1-11.

Cogburn, D.L. and Adeya, K. 1999. Globalisation and the information economy: challenges and opportunities for Africa Economic Commission for Africa, African Development Forum. [Online].

Available WWW: http://www.bellanet.org/partners/AISI/adf99docs/infoeconomy.htm.

Forsyth, G. 1988. Championing the knowledge economy. [Online].

Available WWW:

http://www.hkbu.edu.hk/Xhktug/newsltr/1998/mar/knowledge_economy.html.

Global Information Infrastructure Commission. 2002. The GIIC mission statement.

[Online].

Available WWW: http://www/giic.org.

Grulke, W.E. 1995. South Africa's business paradigm: catch-up or leap-frog? [Online].

Available WWW: http://www.futureworld.co.za/talkbexa.html.

Henderson, J.C. 2000. Competing in the knowledge economy. [Online].

Available WWW: http://www.acnielsen.com/pubs/ci/2000/q3/features/competing.htm.

Hendry, J.D. 2000. Social inclusion and the information poor. Library Review 49(7)1-8.

ITWeb. 2001. African data traffic on the increase In: NUA Internet. [Online].

Available WWW: http://www.nua.net/surveys/index.cgi?

$\underline{\mathrm{f}=\text { VSandart_id=905357425rel=true. }}$

Information Infrastructure Task Force. 1994. What it takes to make it happen: key issues for applications of the National Information Infrastructure. [Online].

Available WWW: http://sunsite.unc.edu/nii/NII-Executive-Summary.html.

James, T. 2001. An information policy handbook for southern Africa: a knowledge base for decision makers IDRC. [Online].

Available WWW: http://www.apc.org/books/ictpolsa/ch5/ch5-6.htm.

Madon, S. 2000. The Internet and socio-economic development: exploring the interaction. Information Technology and People 13(2)85-101.

Media Africa. 2000. South Africa sees Internet soar. [Online].

Available WWW: http://www.nua.net/surveys/index.cgi?

$\mathrm{f}=$ VSandart_id=905355985andrel=true.

National Information Infrastructure. 1997. [Online].

Available WWW: http://nii.nist.gove/nii/whatnii.html.

Selwyn, N. 1999. Education superhighways - in the public or private interest? Internet Research: Electronic Networking Applications and Policy 9(3)1-8. 
Selwyn, N. and Brown, P. 2000. Education, nation states and the globalisation of information networks. Journal of Educational Policy 15(6)661-682.

South Africa Department of Foreign Affairs. 2001. A new African Initiative: Merger of the Millenium Partnership for the African Recovery Programme (MAP) and the Omega Plan Document to be adopted by the OAU Heads of State Summit from 09-11July 2001.

Trade and Industrial Strategy Policies. 2002. [Online]

Available WWW: http://www.tips.easydata.co.za.

United Nations Development Programme. 2001. Making new technologies work for human development: human development report 2001 New York: Oxford University Press.

United States Internet Council. 2000. State of the Internet 2000. [Online].

Available WWW: http://isic.wslogic.com/intro.html.

University of Pretoria. 2001. E-commerce growing in South Africa In: NUA Internet.

[Online].

Available WWW: http://www.nua.net/surveys/index.cgi?

$\mathrm{f}=$ VSandart_id=905357139rel=true.

Vaile, M. 2000. Australia and the knowledge economy. [Online].

Available WWW: http://www.dfat.gov.au/media/speeches/trade/2000/001031_eiu.html .

Worthington-Smith, R. 2001. E-business handbook. The 2001 review of how South African companies are making the Internet work. Cape Town: Trialogue.

\section{Disclaimer}

Articles published in SAJIM are the opinions of the authors and do not necessarily reflect the opinion of the Editor, Board, Publisher, Webmaster or the Rand Afrikaans University. The user hereby waives any claim he/she/they may have or acquire against the publisher, its suppliers, licensees and sub licensees and indemnifies all said persons from any claims, lawsuits, proceedings, costs, special, incidental, consequential or indirect damages, including damages for loss of profits, loss of business or downtime arising out of or relating to the user's use of the Website. 
ISSN 1560-683X

Published by InterWord Communications for the Centre for Research in Web-based Applications, Rand Afrikaans University 